\title{
Upaya Meningkatkan Hasil Belajar Sistem Operasi Open Source Komputer Multi Media Melalui Model Pembelajaran Diskusi dan Eksperimen
}

\author{
YAYAH NUR ALIYAH* \\ Guru SMK Negeri 48 Jakarta \\ aliyahyayahnur@gmail.com
}

\begin{abstract}
The research was purposed to find out the effectiveness of discussion and experiment models are able to improve study result of students in operation system computer open source of multimedia learning in X Multimedia in SMKN 48 at Academic Year 2014/2015. The reasearch was conducted on July-Desember 2014. The method of the research was Action Research (PTK) which was conducted in two cycles. Discussion and Experiment were used as learning cycle model. A cycle consisted in three times of meetings and in the third meeting was done Post test. The indicators have been achieved by the result of research. As the expectation, in the second cycle, namely the number of students got the highest points was $97,45 \%$ of 32 Students and average value was $80,79 \%$. The completeness of students was achieved and students did negative activity was not more than $35 \%$ but only 1,55\%. In the second cycle can be said that achievements of students learning have improved by using discussion and experiment learning model. Giving special attention to Less-achievement and Passive Students of work at monitoring group discussion and experiment. In conclusion, discussion and experiment are able to improve students' study result in operation system computer open source of multimedia learning if it was implemented appropriately in X Multimedia in SMKN 48 Jakarta.
\end{abstract}

Keywords : Discussion, Experiment, and Operation system open source 


\section{PENDAHULUAN}

Materi Pelajaran Sistem Operasi Komputer ini termasuk salah satu mata pelajaran kelompok Program Keahlian Multimedia Kelas Xdi SMK Negeri 48 Jakarta.

Prestasi Akademik siswa rendah yakni antara $65 \%$ sampai $80 \%$ yang menguasai konsep. Dengan menerapkan Model Pembelajaran Diskusi dan Eksperimen, Materi PembelajaranSistem Operasi Open Source dapat meningkatkan prestasi belajar Siswa kelas X Multimedia di SMK Negeri $48 \quad$ Jakarta. Untuk mengaktifkan siswa dalam proses pembelajaran dan untuk menfokuskan perhatian siswa pada materi sistem operasi yang diberikan pada saat proses pembelajaran berlangsung perlu usaha yang keras, hal ini menjadi tantangan bagi Penelitidalam memberikan materi pelajarannya tentang Perkembangan Sistem Operasi Open Source, unix, Linux dan lain sebagainya.

Dalam rangka pelaksanaan 8 Standar Nasional Pendidikan Tentang Standar Kompetensi Kelulusan untuk SMK Negeri 48 Jakarta, Kompetensi keahlian Multimedia dalam rangka memenuhi dunia kerja yang diserap pada dunia usaha/dunia industri, perlu adanya pengembangan diri dalam bidang pemahaman pelajaran Multimedia dalam kelompok mata pelajaran produktif Multimedia yaitu mampu dalam pengembangan system operasi open sourceyang dapat membuat pembelajaran sebagai pembentukan kepribadian diri bagi siswa Multimedia Untuk itu peneliti sebagai guru bidang studi Multimedia merasa tergerak untuk mengembangkan diri siswadalam bidang kemampuan pembentukan kepribadian seorang ahli computer.

SMK Negeri 48 Jakarta perlu mempersiapkan ilmu serta dan mengkondisikan serta selalu mengoptimalkan Siswa Multimedia khususnyakelas $\quad X$ MM untuk menyiapkan siswa dalam mengikuti praktek kerja industri kelak dikelas selanjutnya nanti sehingga dapat menyesuaikan diri dengan Profil dan Karakteristik yang telah diterapkan yaitu; Menyiapkan siswa Multimedia sesuai standar kebutuhan berdasarkan jumlah dan kwalifikasi baik.

Dalam pembelajaran, guru dan siswa masing-masing mempunyai peranan yang penting dalam rangka pencapaian tujuan pembelajaran, dimana siswa dalam proses pembelajaran harus aktif agar tujuan pembelajaran dapat tercapai, mata pelajaran Multimedia, tidak terlepas dari kurikulum yang dikembangkan oleh sekolah yakni Kurikulum Tahun 2013 yang berpedoman kepada Peraturan Pemerintah No 19 tahun 2005 tentang Standar Nasional Pendidikan bahwa standar proses pembelajaran pada satuan pendidikan diselenggarakan secara interaktif, inspiratif, menyenangkan, menantang, dan memotivasi siswa untuk berpartisipasi aktif, serta memberi ruang yang cukup bagi siswa untuk dapat menuangkan prakarsa, kreativitas, dan kemandirian sesuai dengan bakat, minat, dan perkembangan fisik serta psikologis siswa.

Prestasi Akademik siswa rendah yakni antara $60 \%$ sampai $70 \%$ yang menguasai konsep. Dengan Model Pembelajaran Demostrasi dan Presentasi, diharapkan akan meningkat kan hasil belajar siswa kelas X MM.

Nilai hasil belajar mata pelajaran produktif di kelas $X \mathrm{MM}$. rendah yaitu rata-rata $60 \%$ dibawah $\mathrm{KKM}$,adapun KKM Mata Pelajaran Multimedia ini pada sekolah Peneliti adalah 76 karena sekolah SMK Negeri 48 Jakarta, alternative lainnya dengan melakukan inovasi dan pendekatan pembelajaran, baik dalam menggunakan media ataupun metode penyampaian pembelajaran ini. 
Tidak efektifnya pembelajaran Materi Pelajaran Produktif Multimedia tersebut, namun pembelajaran menggunakan pembelajaran meningkatkan Kelas X MM. Peneliti sadar,bahwa selama ini belum metode dan mode yang bervariasi dalam hasil belajar Siswa

Tujuan dalam pembelajaran pada dasarnya merupakan rumusan tingkah laku dan kemampuan-kemampuan yang harus dicapai dan dimiliki para siswa setelah menyelesaikan kegiatan belajar dalam proses belajar mengajar

Berdasarkan masalah diatas, maka Peneliti akan melakukan Penelitian Tindakan Kelas denganmenerapkan Model Pembelajaran Demonstrasi dan Presentasi dalam pembelajaran Mata Pelajaran Produktif Multimedia dengan Sistem Operasi Open Source melalui materi Perkembangan Sistem Operasi Open Sourcedi kelas X MM, SMK Negeri 48 Jakarta.

Rumusan Masalah

Masalah dalam penelitian ini adalah sebagai berikut Apakah penggunaan model pembelajaran Demonstrasidan Presentasi dapat meningkatkan prestasi hasil belajar siswa pada Pembelajaran Sistem Operasi di kelas XMM dengan materi Perkembangan Sistem Operasi Open SourceKompetensi Keahlian Multimedia pada SMK Negeri 48 Jakarta pada Semester Ganjil Tahun 2014/ 2015.

Tujuan Penelitian

Tujuan yang ingin dicapai dalam penelitian tindakan kelas ini adalah :

Untuk mengetahui efektifitas penggunaan model pembelajaran Demonstrasi dan Presentasi dalam Meningkatkan Prestasi Hasil Belajar siswa pada Mata Pelajaran Produktif Multimedia, khususnya tentang materi Sistem Operasi dengan materi Multimedia Kompetensi Keahlian Multimedia pada Semester Ganjil Tahun 2014/2015 di SMK Negeri 48 Jakarta.

\section{DESKRIPSI TEORITIS}

A.Hasil Belajar

Hasil dimana guru melihat bentuk akhir dari pengalaman interaksi edukatif yang diperhatikan adalah penempatan tingkah laku (Winarno Surahmad 1977: 88), Hasil belajar merupakan hasil dari proses kompleks, hal ini disebabkanbanyak faktor yang terkandung didalamnyabaik internal maupun eksternal.

Manusia mengadakan interaksi dengan dunia luar dengan menggunakan simbolsimbol. Kemampuan belajar cara inilah yang disebut "kemampuan Strategi Kognitif". Ini merupakan organisasi keterampilan yang internal (internal organized skill) yang perlu untuk belajar mengingat dan berpikir. Kemampuan ini berbeda dengan kemampuan intelektual, karena ditujukan ke dunia luar, dan tidak dapat dipelajari hanya denganberbuat satu kali serta memerlukan perbaikanperbaikan secara terus menerus. Kemampuan ini belajar tidak akan berhasil dengan baik.

A. Prestasi Belajar

Proses belajar yang dialami oleh siswa menghasilkan perubahan-perubahan: dalam bidang pengetahuan atau pemahaman, dalam bidang keterampilan, dalam bidang nilai, dan sikap Adanya perubahan itu tampak dalam prestasi belajar yang dihasilkan oleh siswa terhadap pertanyaan, persoalan, tugas yang diberikan oleh guru.

B. Hakekat Pembelajaran

Pembelajaran Produktif Multimedia dengan standar kompetensi Sistem Operasi, dengan materi perkembangan sitem operasi open source, merupakan kelompok mata pelajaran produktif Multimedia ini merupakan bagian dari ilmu yang memiliki

Produktif Multi media lainnya.

Oleh karena itu, para ahli komputer harus mampu melakukan kerja ilmiah dalam 
menyelesaikan masalah atau mencari jawaban permasalahan - permasalahan yang dihadapi.

C. Pembelajaran Demonstrasi dan

Presentasi

Model pembelajaran Demonstrasi dan

Presentasi dikembangkan untuk

mencapai tujuan penting pembelajaran, yaitu hasil belajar akademik, penerimaan terhadap keragaman, dan pengembangan keterampilan sosial .

Pembelajaran Demonstrasi dan

Presentasi, merupakan model

pembelajaran dengan siswa bekerja

dalam kelompok yang memiliki

kemampuan heterogen, untuk

mendemonstrasikan materi yang

diajarkan saat itu.

PembelajaranDemontrasi dan

Presentasi sebagai sekumpulan strategi mengajar yang digunakan guru agar siswa saling membantu dalam mempelajari sesuatu.Dan mempresentasikan dihadapan kelompok.

Pembelajaran Model Demonstrasi dan Presentasi dilaksanakan mengikuti tahaptahap sebagai berikut :

a. Menyampaikan tujuan pembelajaran dan perlengkapan pembelajaran.

b. Menyampaikan informasi

c. Mengorganisasikan siswa ke dalam kelompok-kelompok belajar

d. Membantu siswa belajar dan bekerja dalam kelompok.

e. Evaluasi atau memberikan umpan balik.

f. Memberikan penghargaan

g. Mendemonstrasikan

dan

Mempresentasikan

D. Tujuan Pembelajaran Demonstrasi dan Presentasi

Tiga tujuan pembelajaran emonstrasi dan presentasi sebagai berikut :

1. Meningkatkan kinerja siswa dalam tugas-tugas akademik. Beberapa ahli berpendapat bahwa model ini unggul dalam membantu siswa memahami konsep-konsep yang sulitdalam angka-angka bidang .
2. Penerimaanyang luas terhadap

Orangyang berbedamenurut ras,budaya,kelas sosial

kemampuan maupun

ketidakmampuan.Mengajarkan

untuk saling menghargai satu

samalain.

3. Mengajarkan kepada siswa

keterampilan kerjasama dan

kolaborasi. Kemampuan ini

penting karena banyak anak muda dan orang dewasa masih kurang dalam keterampilan komputer.

E. Kemampuan Pembelajaran Model Demontrasi danPresentasi

Melalui model ini diharapkan tidak cuma kemampuan akademik yang dimiliki siswa tetapi juga ketrampilan yang lain. Keterampilan-keterampilan itu antara lain:

1. Keterampilan-keterampilan komputer .

2. Keterampilan sosial dan berbagi

3. Keterampilan berperan serta

4. Keterampilan - keterampilan.

Komunikasi

5. Pembangunan tim

6. Keterampilan-keterampilan kelompok.yang lain di jurusan.

Model Demonstrasi dan Presentasi merupakan menunjukan dengan nyatayaitu tehnik yang dikembangkan untuk memberi siswa kesempatan untuk bekerja sendiri serta bekerja sama dengan orang lain. Keunggulan dan tehnik ini adalah optimalisasi partisipasi siswa, yaitu memberi kesempatan delapan kali lebih banyak kepada setiap siswa untuk dikenali dan menunjukkan partisipasi mereka kepada orang lain.

Strategi simulasi yang digunakan oleh para guru menerapkan langkah-langkah sebagai berikut:

Tahap-1: Thinking (berfikir) 
Tahap-2: Pairing

Tahap-3: Sharing

Kelebihan model pembelajaran Demonstrasi dan Presentasi adalah:

1. Memungkinkan siswa untuk merumuskan dan mengajukan pertanyaan-pertanyaan mengenai materi yang diajarkan, karena secara tidak langsung memperoleh contoh pertanyaan yang diajukan oleh guru, serta memperoleh kesempatan untuk memikirkan materi yang diajarkan dan mendemonstrasikan serta mempresentasikan

2. Siswa akan terlatih menerapkan konsep karena bertukar pendapat dan pemikiran dengan temannya untuk mendapatkan kesepakatan dalam memecahkan masalah.

3. Siswa lebih aktif dalam pembelajaran karena menyelesaikan tugasnya dalam kelompok, dimana tiap kelompok hanya terdiri dari 2 orang,

4. Siswa memperoleh kesempatan untuk mendemonstrasikan mempersentasikan hasil diskusinya dengan seluruh siswa sehingga ide yangada menyebar,

5. Memungkinkan guru untuk lebih banyak memantau siswa dalam prosespembelajaran.

Kelebihan

pembelajaran

Demonstrasi adalah sebagai berikut:

1. Membantu siswa untuk respek pada orang lain dan menyadari akan segala keterbatasannya serta menerima segala perbedaan.

2. Siswa dapat mengembangkan kemampuan untuk menguji ide dan pemahamannya sendiri dan menerima umpan balik.

3. Interaksi yang terjadi selama pembelajaran dapat meningkatkan motivasi dan member rangsangan untuk berpikir sehingga bermanfaat bagi proses pendidikan jangka panjang.

4. Pembelajaran model Demonstrasi dan Presentasi bias mengajarkan orang untuk bersama-sama dan lebih efisien, biasanya kegiatan praktikperlu dilakukan dalam jangka waktu tertentu. Dengan bekerja sama, dua orang dapat menyelesaikansesuatulebihcepat.)

F. Hipotensis Tindakan

Dengan metodeDemonstrasi

dan Presentasi , dapat meningkatkan hasil belajar mata pelajaran Multimedia dengan Perkembangan Sistem Operasi Open Source pada kelas X MM di SMK Negeri 48 Jakarta. Kompetensi Keahlian Multimedia.

Kegiatan Penelitian Tindakan Kelas ini memfokuskan pada peningkatan hasil dan prestasi belajar siswa dalam mengikuti pelajaran Multimedia yang terintegrasi dari beberapa Kompetensi Dasar Kejuruan kompetensi Keahlian Multimedia, yang harus dimiliki oleh siswa Kelas $X$ MM yang juga merupakan pembentukan kepribadian dan karakter Mata Pelajaran Multimedia dalam Perkembangan Sistem Operasi Open Source.

Kebijakan Dinas pendidikan yang mengharuskan sekolah untuk menerapkan 8 standar pendidikan, hal ini membuat peneliti untuk mencari strategi yang efektif agar permasalahan tersebut dapat menghasilkan kebijakan yang mampu meningkatkan prestasi belajar dan daya saing tamatan dalam dunia Kerja (DU/DI). 
METODE PENELITIAN

1. Setting Penelitian Lokasi Penelitian:SMK Negeri 48 Jakarta.

Subyek Penelitian: Siswa Kelas X MM , sebanyak 32 siswa

Waktu Penelitian: 6 Bulan Juli s/d Desember 2014.

2. Prosedur Penelitian

Dalam penelitian ini dilakukan dua siklus dan tiap siklus tiga pertemuanPelaksanaan Tindakan Presentasi dapat digunakan / diteruskan sebagai model pembelajaran disekolah.

Tehnik Pengumpulan Data .

Pengumpulan data dilaksanakan melalui tahapan sebagai berikut :

Studi dokumen berupa hasil kinerja siswa tiap kelompok, Observasi terhadap aktivitas dikelas X MM. SMK Negeri 48 Jakarta, pada saat pembelajaran MultimediaSistem Operasi, materi Perkembangan Sistem Operasi Open Source, selama berlangsung PTK pada siklus 1 maupun 2 .

Observasi

kedisiplinan,

aktifitas dikelas,

meliputi :

minat belajar,

pendapat teman.

Evaluasi hasil belajar / ulangan harian sebelum dan selama berlangsung PTK dalam siklus 1 dan Siklus 2.

\section{DEKRIPSI HASIL PENELITIAN}

Aktifitas / penilaian kinerja siswadalam diskusi kelompok.Penilaian kinerja siswa / aktifitas siswa dalam hal menyelesaikantugas kelompok selama proses.Kebiasaan siswa yang akandiperhatikan pada penelitian inicenderung kepada kebiasaan siswayang bersifat negative. Siswa yangtidak semangat pada saat prosespembelajaran akan melakukan.
Dari observasi kebiasaan negative siswa pada siklus pertama,diperoleh gambaran kebiasaan negative siswa menonjol pada kebiasaan ngobrol/mengganggu teman dan jalan-jalan ke kelompok lain pada saat diskusi atau proses belajar berlangsung. Pada pertemuan pertama siswa yang ngobrol ada 10 orang, jalan ke kelompok lain ada 4 orang, diam saja ada 4 orang, purapura sibuk 2 orang, sedangkan yang main HP tidak ada satu orangpun. Jumlah siswa yang melazkukan kebiasaan negative ini tidak terlalu banyak,hanya kurang lebih 6,15\% saja dari total jumlah siswa

NilaiPost test Siswa.

Refleksi Siklus 1

Dari hasil observasi pada siklus , penelitimenemukan keberhasilan dan kegagalan dari tindakan yang diberikan, pada tahap awal pembelajaran masih ada siswa yang tidak perhatian terhadap proses pembelajaran, yaitu adanya siswa yang ngobrol dan jalan-jalan ke kelompok lain, tetapi setelah diberi pengertian bahwa setiap siswa harus aktif menjawab pertanyaan dalam LKS maka pada pertemuan kedua mereka sudah tidak melakukannya lagi .

Kehadiran siswa dalam mengikut proses pembelajaran sangat baik, hanya ada dua orang tidak masuk karena sakit, jadi mereka mempunyai kemauan yang baik untuk mengikuti pelajaran di kelas.

Dari aspek-aspek yang diamati, pelaksanaan pembelajaran belum mencapai indikator yang diharapkan, nilai rata-rata post testsiswa padasiklus pertama ini hanya 78,28 dan siswa yang mencapai nilai batas

penting atau materi essensial yang harus dipahami oleh para siswa dan mengoptimalkan tanya jawab serta memberi perhatian yang lebih kepada siswa yang kurang aktif.

sedikit yang melakukan kebiasaan negative, yakni hanya $0,77 \%$. Hal ini disebabkan karena mereka sadar bahwa 
nilai post test pada siklus 1 sebagian besar tidak tuntas, tampaknya mereka sadar betul bahwa dalam belajar perlu konsentrasi dan usaha yang sungguhsungguh

Refleksi Siklus 2

Pada siklus ke 2 ini peneliti melihat bahwa pelaksanaan model pembelajaran

Demostrasi dan Presentasi telah dapat meningkatkan prestasi belajar siswa, dan mencapai indikator penelitian yang ditetapkan yakni persentase siswa yang mencapainilai tuntas adalah $100 \%$, persentase rata-rata siswa yang aktif melakukan diskusi dalam proses pembelajaran lebih dari $90 \%$ dan yang melakukan kebiasaan negative kurang dari 10\%.Dengan demikian dapat dikatakan bahwa pelaksanaan pembelajaran dengan Model Demonstrasi dan Presentasi dapat meningkatkan prestasi belajar siswa.

Berikut ini adalah data hasil penelitian dari semua siklus yang akandianalisis

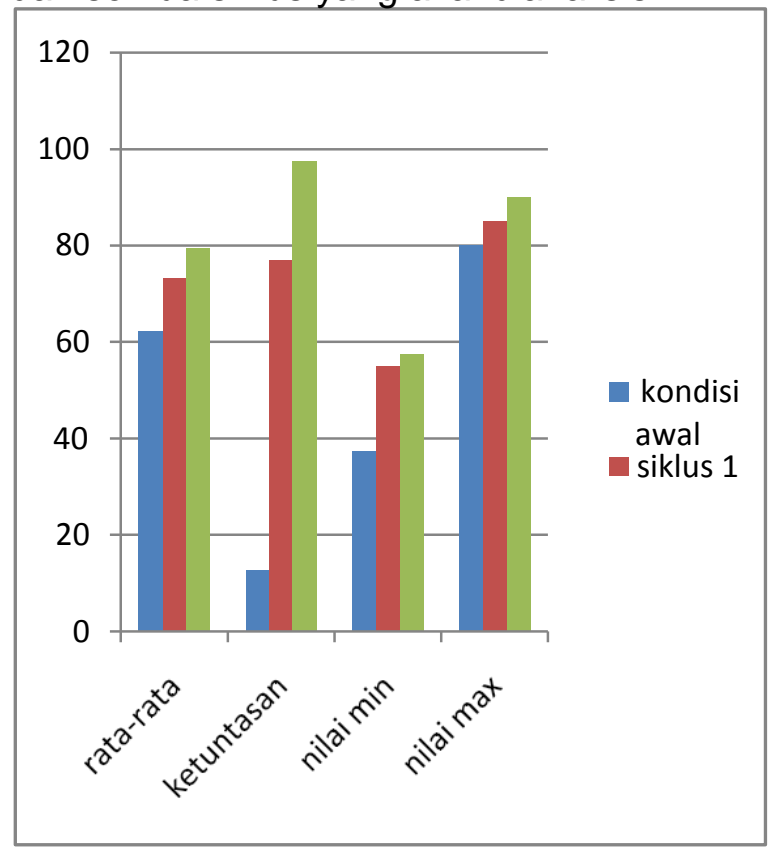

Tindakan yang diberikan pada pembelajaran dengan model Diskusi dan Eksperimen dengan memberikan penguatan oleh peneliti pada siklus 2 telah dapat meningkatkan prestasi belajar
Materi Pelajaran Sistem Operasi Open Source di kelas X MM.

Dari table di atas dapat dilihat bahwa pada siklus 1, jumlah siswa yang terlibat aktif dalam diskusi sekitar $85 \%$, mereka kurang aktif bertanya menggali konsepkonsep materi pokok dan cenderung diam saja merasa puas karena sudah menjawab pertanyaan dalam LKS tanpa ingin tahu lebih dalam lagi mengenai materi pelajaran yang sedang dibahas.

Ketidakaktifan sebagian siswa tidak serta merta menyebabkan siswa melakukan kebiasaan negative. Hal ini bisa di lihat dari persentase siswa yang melakukan kebiasaan negative jumlahnya hanya $5 \%$ - Tapi ketidakaktifan siswa berakibat pada hasil nilai post test. Ketidak aktifan ini menyebabkan diskusi tidak berkembang sehingga materi yang dibahas tidak lebih dalam atau pemahaman siswa terbatas kepada apa yang ditanyakan dalam LKS saja sehingga ketika ditanya dalam lembaran soal post testmereka banyak salah menjawab. Hal ini dapat dilihat dari persentase jumlah siswa yang mendapat nilai batas tuntas 76 hanya sekitar 89,92 $\%$, hasil ini tidak mencapai indikator yang telah ditetapkan yaitu minimal $95 \%$.

Adapun pada siklus 2 , diberikan perlakuan tambahan yaitu setelah selesai melakukan proses pembelajaran dengan model Diskusi dan Eksperimen, menjelang dilakukan post test. Peneliti memberi penjelasan tambahan atau penguatan tentang materi yang dipelajari yaitu topic Memahami, Menyajian dan Mngembangkan Sistem Operasi Proses Booting melalui eksperimen, ternyata dengan memberi perlakuan tambahan tersebut dapat meningkatkan nilaihasil post test pada siklus 2, yakni jumlah siswa yang mendapatkan nilai sampai batas tuntas atau melebihi batas tuntas, sebanyak $100 \%$ dan nilai rata-rata mencapai 97,42.

Persentasi ketuntasan siswa telah dapat mencapai indikator yang diharapkan dalam penelitian ini, dan siwa yang melakukan kegiatan negatifpun 
Pada siklus 2 ini dapat dikatakan bahwa prestasi belajar siswa kelas $\mathrm{X}$ Multi Media telah meningkat dengan menggunakan model pembelajaran diskusi dan Eksperimen .

\section{SARAN}

Mengacu pada kesimpulan diatas maka peneliti /penulis menyampaikan saran-saransebagai berikut ;

Berdasarkan hasil penelitian, tindakan kelas yang diberikan dalam Model pembelajaran Diskusi dan Eksperimen dapat meningkatkan prestasi belajar mata pelajaran Sistem Operasi Open Source ini bagi siswa Kelas $X$ MM Oleh karena itu para guru dihimbau untuk menggunakan model pembelajaran Diskusi dan Eksperimen ini dalam kegiatan pembelajaran di kelas dan diharapkan guru untuk terus bereksplorasi dalam menemukan strategi yang efektif guna menigkatkan hasil/ prestasi belajar Kompetensi ProduktifProgram Keahlian Multi Media. Disarankan kepada para guru agar lebih jeli dalam menentukan rencana Penelitian Tindakan Kelas yang diberikan sehingga tindakan yang diberikan tidak menimbulkan masalah baru dan membuat siswa meningkat hasil belajarnya .

Pembelajaran Sistem operasi ini mengunakan metode pendekatan scientifik, untuk itu guru dann sekolah wajib mengembangkan diri untuk mengikuti kemajuan teknologi saat ini agar proses belajar dapat berjalan sesuai dengan keinginan yang diharapkan sekolah, mengentaskan tamatan agar terserap di duna usaha industri.

\section{DAFTAR PUSTAKA}

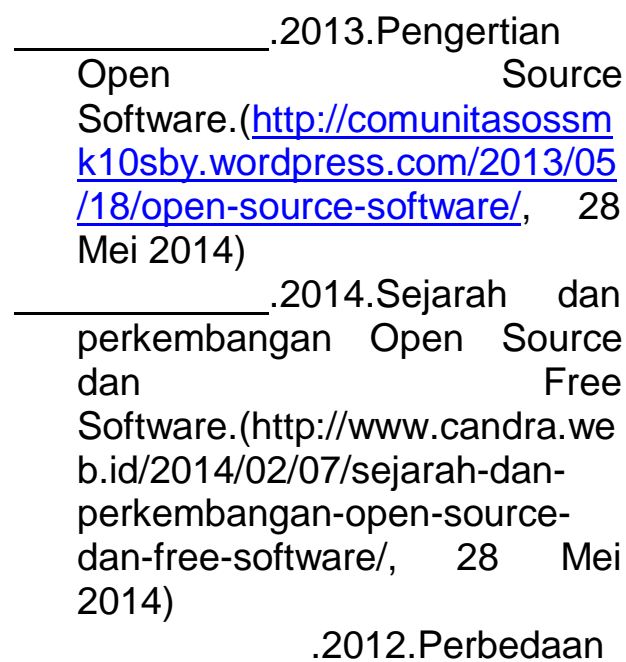

Freeware,Shareware, dan Open Source.(http://amimatsu.blogsp ot.com/2012/11/perbedaanfreeware-shareware-danopen.html, 28 Mei 2014) 2013.Kelebihan dan kekurangan program berbasis open source. (http://komunitas-ossmkdrsoetomosby.blogspot.co m/2013/05/kelebihan-dankekurangan-program.html, 28 Mei 2014)

2013.(http://dea stiyatin.blogspot.com/2013/03/k arakteristik-open-source-danfreeware 8.html, 28 Mei 2014) 